Digital Press Social Sciences and Humanities

Visitors' Management in Borobudur Park, Indonesia

Marcelina Chintia Devi and Diana Kesumasari

Proceeding of Indonesia Heritage Tourism Forum 2019 (IHTF 2019)

Dewi Pratika Ayu Dhira Pradati (eds) 


\title{
Visitors' Management in Borobudur Park, Indonesia
}

\author{
Marcelina Chintia Devi1 ${ }^{1,}$, Diana Kesumasari ${ }^{2}$ \\ 1 Yayasan Rumah Kreasi Indonesia, Desa Tegalmulyo RT. 02, RW. 04, Gajahan, Colomadu, Karanganyar 57176, Jawa Tengah, \\ Indonesia \\ 2 Department of Architecture, Universitas Surakarta, Jl. Raya Palur Km. 5 Surakarta, 57772, Jawa Tengah, Indonesia \\ *e-mail: chintia_marcelina@hotmail.com
}

\begin{abstract}
Issues related to the Borobudur Temple are not merely regional concerns. Aside from being included in the National Tourism Strategic Zone, Borobudur Temple is also included by UNESCO as a World Cultural Heritage. This study aims to evaluate the visitors' management within the area that plays a role as the site's educational purpose. The purpose achieved is observed through the visitors' interpretation. This study conducted several methods to collect data and information, among other field observation, personcentered mapping, photo documentation, and questionnaire. The results of this study are most domestic visitors did not visit supporting attractions, such as Karmawibhangga Museum and Samudraraksa Ship Museum, that provide the educational purpose. This condition was caused by three reasons, a) visitors were tired after climbing the Borobudur Temple, b) the locations of the museums were not strategic, and c) the condition of the museums were less attractive. Most international visitors visited supporting attractions and use a tour guide who have proper and comprehensive knowledge about Borobudur Temple's history and meaning. Through this study, it is expected that the Borobudur Park management authorities can develop a better strategy for managing visitors' movements so that the Borobudur Park purpose of tourists education is achieved.
\end{abstract}

\section{Keywords}

interpretation, visitors, world cultural heritage

\section{Introduction}

The issue of cultural heritage areas and cultural heritage areas as tourism objects is a problem that continues to be an ongoing debate. This problem is an important issue in the scope of both heritage and tourism studies. At the point of conservation view, "protection, conservation, interpretation, and presentation of heritage are important challenges for now and future generations". But some might also argue that cultural heritage is a promising niche for the tourism industry as cited by Diarta (2017).

Indonesia has many Buddhist sites which are also cultural tourism destinations. One of them is Borobudur Temple. This largest Buddhist temple was developed by King Samaratungga from the Syailendra Dynasty which ruled between 760 and 830 AD. Apart from being a cultural tourism destination, Borobudur Temple is also often used as a place of Buddhist religious events to this day (Hermawan, Salim, Rohman, \& Rahayu, 2016). Issues related to Borobudur Temple are not merely regional concerns. Its existence as a historical building and a cultural heritage have positioned it as a prime tourist attraction in Indonesia. Being listed in World Cultural Heritage Number 592 by UNESCO since 1991, the national government includes Borobudur Temple Area in the National Strategic Tourism Area (KSPN) along with 88 other strategic areas, based on the National Tourism Development Master Plan (RIPPARNAS) (Devi, 2017).

Taman Wisata Candi Borobudur (TWCB) or Borobudur Temple Tourism Park is a part of the Borobudur Zone which is used for tourism. Based on Presidential Decree No.1 year 1992 (1992), Borobudur zone covers two zones (Fig. 1). Zone 1 is an archaeological environment area designated for the protection and preservation of the physical environment of the temple. It is managed by Balai Konservasi Cagar Budaya (Conservation Institute of Cultural Heritage). While zone 2 which is managed by PT. Taman Wisata Candi Borobudur, is designated for Tourist Park, which serves as a place for tourism, research, culture, and preservation of the temple environment. 


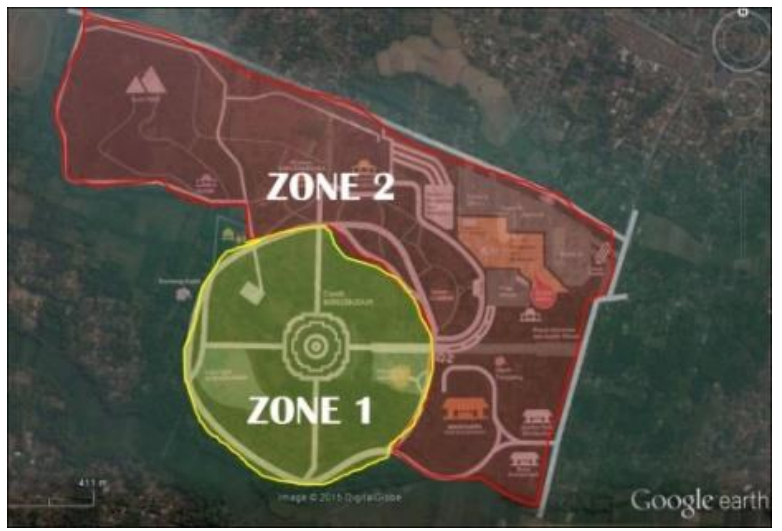

Note:

Zone 1, An area for Borobudur Temple is approximately $44.8 \mathrm{Ha}$, and it is circular with the center point on the temple's axis.

Zone 2, An area for Borobudur Temple is approximately $42.3 \mathrm{Ha}$.

Fig. 1 Zoning in TWBC Source: Author

Tourism Park, the second zone part of TWCB is a park around the temple and all its facilities that are built under the Master Plan for the Development of the National Archaeological Park (Presidential Decree No.1 Year 1992). The usefulness of the temple tourism park other than as a green belt (Balai Konservasi Borobudur, 2014), include:

1. to break up the flow of visitors to various attractions in the park, so that all visitors do not head to the temple at the same time (carrying capacity is not exceeded),

2. give visitors the opportunity to see the temple from a distance and different directions and distances,

3. reducing the number of temple climbers by offering them other public facilities such as museums, information center, Conservation Centers that support visitors to learn things about the Borobudur Temple,

4. provide adequate information for visitors about Borobudur from a different perspective (history, architecture, religion, philosophy, art and science knowledge),

5. to be able to instill a sense of love for the motherland for domestic tourists in general and adolescents in particular,

6. to add to the majesty and elegance of the temples surrounded by parks, and

7. to maintain and develop rare plants found in the area.

The Borobudur Studies and Conservation Institute has indicated that the optimal capacity of the temple itself is under 200 visitors at any one time (Horwarth, 2017). Therefore, visitor management is needed so that the existence of the temple is maintained. In term of heritage management, there are some tools and techniques most commonly used to manage heritage visitors (Timothy \& Boyd, 2003), such as:

1. Controlling traffic could be done with some of the tools, such as seasonal closures,

2. Limiting contact between visitors and artifacts, consist of: roping of the sensitive area, video camera in the heritage site, use of overshoes on visitors,

3. Fees and pricing means raising fees during high season can affect the balancing of visitors flow (Fyall \& Garrod, 1998),

4. Providing a way for visitors to leave their mark, for example, is by the use of guest books,

5. Providing high-quality experiences consist of some method, such as provide good service to help create satisfied consumer,

6. Marketing/promotion could be done for example by published literature and website,

7. Hardening the resource talks about landscaping and formal design in the historic area that should include natural and local material. It has similar conditions to original as possible and can be made in paving details, street furniture, and architecture (Booth, 1993).

8. Creating mindful visitors did for creating visitors that can pay more attention to the world around them.

9. Heritage tourism management tools and techniques are illustrated in Fig. 2. 


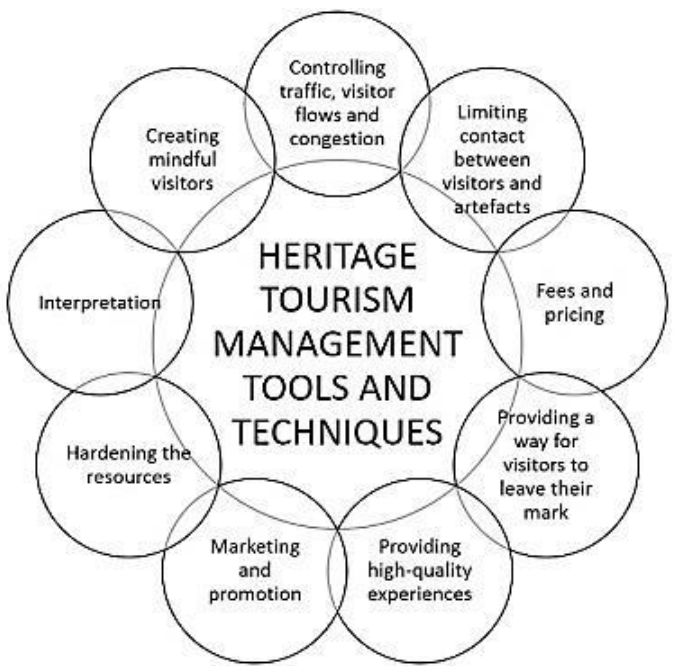

Fig. 2 Heritage tourism management tools and techniques Source: Timothy \& Boyd, 2003

One of the tools and methods that most commonly used to manage heritage visitors is interpretation. The interpretation has two clear objectives: (1) to educate people about the place they are visiting, (2) to provide an enjoyable, and even entertaining, experience for visitors. These two elements work together to increase visitors' respect for heritage and take responsibility for caring for it (Timothy \& Boyd, 2003). Educational purposes for TWCB visitors become one of the most important things in Borobudur's heritage tourism area that has to be considered by management. It is connected with the visitors' understanding of Borobudur temple knowledge that can be directing visitor's behavior in the site. Visitors should consider the sustainability of cultural heritage rather than only think about recreation. Sustainability of cultural heritage can be achieved if visitors have learning motivation to understand about history and why Borobudur is called a World Cultural Heritage, so visitors can also play an active role in maintaining the sustainability of the area. Visitors learning motivation can be stimulated with tour guides as an intermediary for the delivery of knowledge, and supporting attractions for educational purposes.

Supporting the temple which serves as the main site in zone 1, supporting attractions located in zone 2 are required. One of the supporting attractions in zone 2 is the museums. There are two museums in zone 2: Samudraraksa Ship Museum and Karmawibhangga Museum. The museums are expected to help visitors to gain more knowledge about the temple, and its history and future (Wahyuningsih, 2016). Therefore, this research aims to evaluate the visitors' management within the area that plays a role as the site's educational purpose. The educational purpose is achieved when tourists can understand the essence of Borobudur Temple's existence so that it is called a World Cultural Heritage. How far the purpose is achieved, is observed through visitors' interpretation.

\section{Methods}

The research area was focused on Taman Wisata Candi Borobudur/TWCB (Borobudur Temple Tourism Park). The TWCB site plan can be seen in Fig. 3. Space layout and visitors' activities in this research were based on field observation conducted on April-Juni 2019. Field observation was carried out during weekdays and weekends, with three observation times: morning (10.00-12.00), noon (12.00-14.00), and afternoon (14.00-17.00). The visitors observed in this research were divided into two types, namely domestic visitors and international visitors.

In addition to field observation, this research also conducted person-centered mapping, photo documentation, informal interviews, and questionnaires. Qualitative and quantitative data were collected to explore differences in visitors' movement patterns and their relationship to learning motivation. Qualitative data was collected through observation, while quantitative data was collected through questionnaires $(n=155)$. To figure out whether visitors feel motivated to learn about Borobudur Temple as a World Cultural Heritage, informal interviews were carried out.

Visitors' movement patterns in TWCB were recorded through person-centered mapping. A small number of participants ( $\mathrm{n}=10$ groups) was tracked unobtrusively. The recording was started when visitors 
entered the TWCB parking area and ended when visitors left the TWCB area. The purpose of this recording was to find out which areas were usually headed by visitors while in TWCB and whether the area contributed to increasing visitors' knowledge. Data and information were analyzed qualitatively, by comparing physical settings of observation areas, person-centered mapping, and results of informal interviews and questionnaires until the findings that lead to a conclusion were obtained.
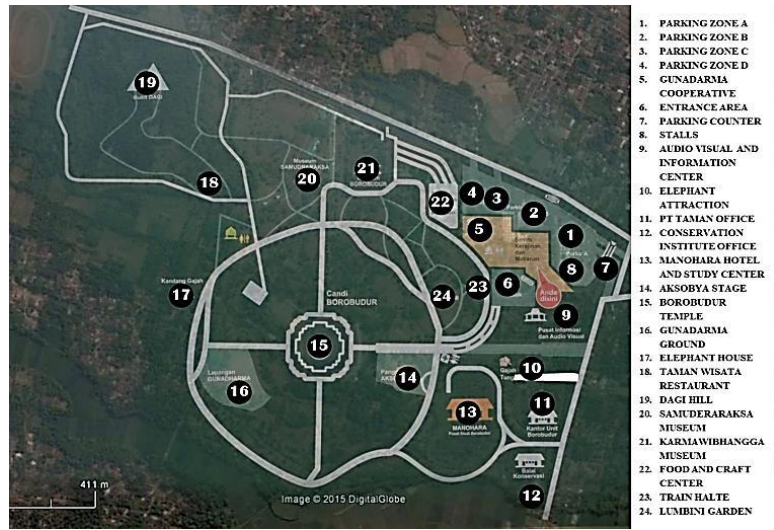

Fig. 3 The TWCB Site plan

Source: Author

\section{Result and Discussion}

\subsection{Questionnaire Results}

Table 1 Visitors' demographic data

\begin{tabular}{|c|c|c|c|}
\hline Demographic Items & Value & Domestics (\%) & International (\%) \\
\hline \multirow[t]{2}{*}{ Gender } & Men & 54 & 50 \\
\hline & Women & 46 & 50 \\
\hline \multirow[t]{6}{*}{ Age } & $<20$ y.o & 32 & 0 \\
\hline & $20-29$ у.о & 32 & 62,5 \\
\hline & $30-39$ у.о & 25 & 37,5 \\
\hline & $30-49$ у.о & 7 & 0 \\
\hline & $50-59$ у.о & 3 & 0 \\
\hline & $>60$ y.o & 1 & 0 \\
\hline \multirow[t]{3}{*}{ Visit Frequency } & $1 \mathrm{x}$ & 35 & 0 \\
\hline & $2-3 x$ & 42 & 50 \\
\hline & $>3 x$ & 23 & 50 \\
\hline \multirow{3}{*}{$\begin{array}{l}\text { The day respondents visited } \\
\text { TWBC }\end{array}$} & Weekday & 20 & 0 \\
\hline & Weekend & 69 & 0 \\
\hline & Random, depending on needs & 11 & 100 \\
\hline \multirow{3}{*}{$\begin{array}{l}\text { When respondents visited } \\
\text { TWBC }\end{array}$} & Morning (10.00-12.00) & 53 & 94 \\
\hline & Noon $(12.00-14.00)$ & 36 & 6 \\
\hline & Afternoon $(14.00-17.00)$ & 11 & 0 \\
\hline \multirow{4}{*}{$\begin{array}{l}\text { With whom respondents } \\
\text { visited TWBC }\end{array}$} & Alone & 3 & 0 \\
\hline & Family & 58 & 0 \\
\hline & $\begin{array}{l}\text { Friends } \\
\text { Coworkers }\end{array}$ & 37 & 100 \\
\hline & Coworkers & 2 & 0 \\
\hline
\end{tabular}

Source: Questionnaire

Illustrated in Table $\mathbf{1}$ is the demographic data of the respondents. In terms of gender, there were no significant differences between the number of domestic and international respondents. The majority of 
domestic respondents who visited TWCB were under 29 years old, while for international respondents, the majority who came were between 20-29 years old. The majority of respondents, both domestic and international visitors had visited TWCB more than 1 times, with the day of visit for domestic respondents is weekend, and international respondents were random days, depending on their needs. Popular visiting hours for both domestic and international visitors were in the morning (10.00-12.00). The majority of domestic respondents came with their families, while for international respondents came with their friends.

From Fig. 4, it is known that the majority of domestic respondents visited TWCB for family recreation (36\%), looking for selfie photo spots (31\%), joining the tour package (18\%), and learning the history of Borobudur Temple (14\%). Whereas $75 \%$ of international visitors came specifically to learn the history of Borobudur temple. The remaining $25 \%$ came because of joining the tour package. For the visit duration, there were no differences between domestic and international respondents. The majority of both visitors were able to spend more than 1 hour at TWCB.

The purpose of respondents visited TWCB

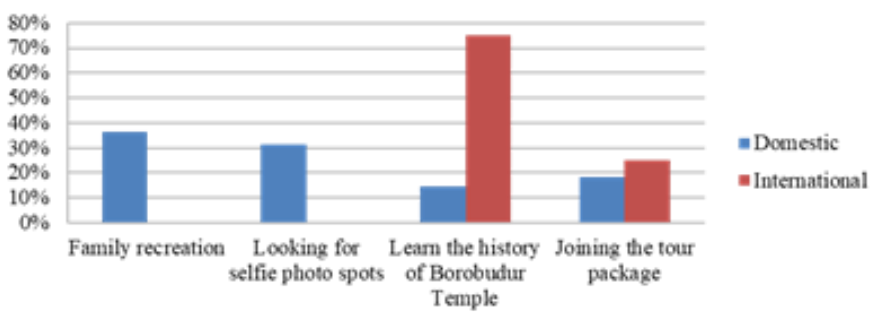

Visit duration in TWCB

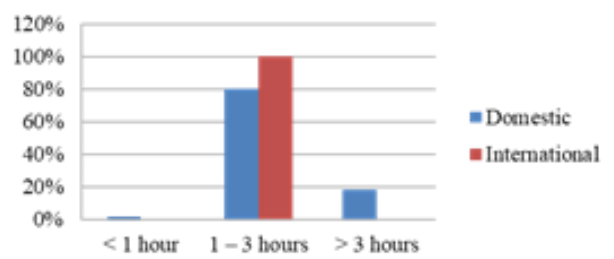

Fig. 4 The purpose of respondents visited TWCB and visit duration in TWCB Source: Author

Areas visited by domestic respondents after Borobudur Temple include vehicle parking (50\%), Samudraraksa Ship Museum (35\%), Food and Crafts Center (8\%), Karmawibhangga Museum (5\%) and Taman Wisata Restaurant (2\%). Areas visited by international respondents after Borobudur Temple include Samudraraksa Ship Museum (50\%), Karmawibhangga Museum (25\%), Vehicle Parking (19\%), and Food and Crafts Center (6\%). Therefore, there was a difference in the destination of places visited after Borobudur Temple between domestic and international respondents.

In TWCB, there are two museums, the Samudraraksa Ship Museum and the Karmawibhangga Museum. The location of the two museums are close, but from the questionnaire result regarding the area visited after from Borobudur Temple, it turned out that a lot of visitors, especially domestic visitors, did not visit these museums. Some reasons that made visitors not visit the Samudraraksa Ship Museum, include: did not know the location of the museum (56\%), tired/ bored after from Borobudur Temple (31\%), uninterested in the content of the museum (11\%), and uninterested because the museum's facade was not interesting (2\%). Several reasons that made visitors not visit the Karmawibhangga museum, include: tired/bored after from Borobudur Temple (41\%), did not know the location of the museum (39\%), uninterested because the museum's facade was not interesting (14\%), and uninterested in the content of the museum (7\%). The area visited after from Borobudur Temple and reasons for not visiting the museums are illustrated in Fig. $\mathbf{5}$.

\section{Respondents felt happy when walking in} TWCB

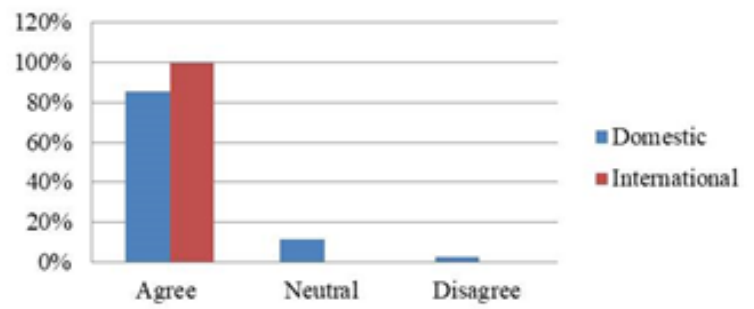

Respondents feel tired after walking in TWCB

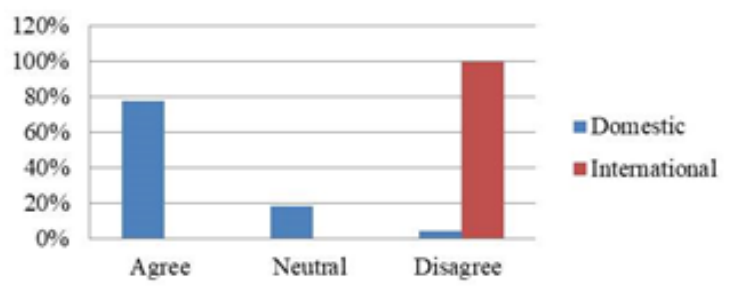

Fig. 5 The area visited after Borobudur Temple and reasons for not visiting the museums Source: Author 
From the questionnaire, it was found that both domestic and international respondents felt happy when walking around in the TWCB. But regarding visitor fatigue, there was a difference. $78 \%$ of domestic respondents said they were tired after walking on TWCB, while $100 \%$ of international respondents said they were not tired after walking on TWCB. The results regarding the respondents' feelings when walking in TWCB can be seen in Fig. 6

Respondents felt happy when walking in TWCB

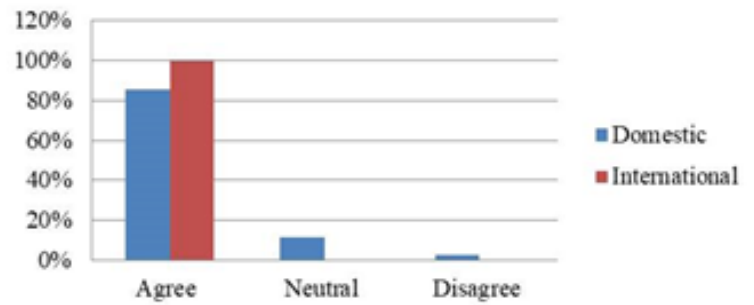

\section{Respondents feel tired after walking in TWCB}

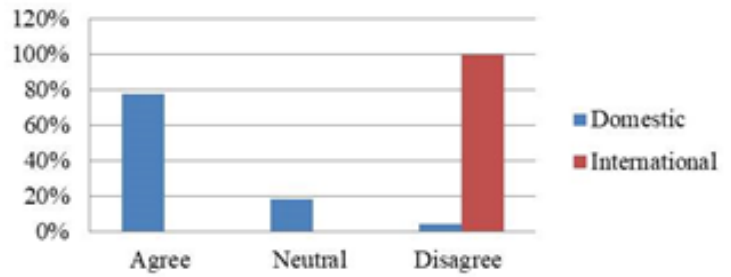

Fig. 6 Respondent's feeling when walking in TWCB Source: Author

The tour guide, who has comprehensive knowledge about the history and meaning of Borobudur Temple, was apparently still not widely used. From the questionnaire results, $62 \%$ of domestic visitors did not use a tour guide, with several reasons such as: unneeded (83\%), expensive (12\%), and did not know that there were tour guides provided by the TWCB manager (6\%). Among international visitors, $94 \%$ used a tour guide, and there was increased knowledge after using the services of a tour guide. A few international visitors did not use a tour guide because they didn't feel need the guide $(6 \%)$. The results regarding the tour guide can be seen in Fig. 7.

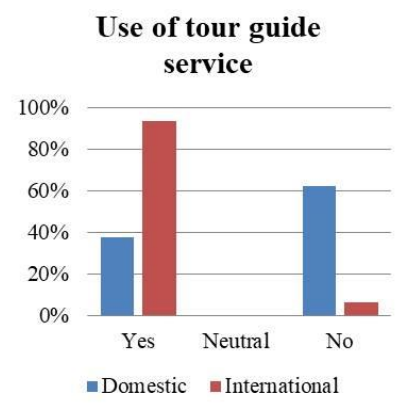

3.2 Observation Results

In addition to Borobudur Temple as the main attraction, the supporting attractions that exist in TWCB in this research were divided into two types, namely:

a. Areas for educational purposes, consisting of the Audio Visual and Information, Samudraraksa Museum, and the Karmawibhangga Museum.

1) Audio Visual and Information is near with entrance area of TWCB. In this area, visitors can get information about TWCB through brochures in several languages, and watch 20 minutes of Borobudur Documentation movie. Visitors have to pay Rp 5.000, 00/ person for watching. The movie will be shown with a minimum of 5 audiences. 


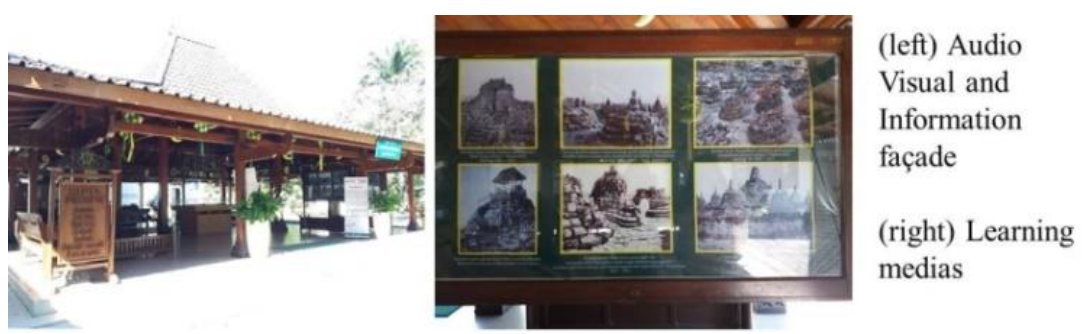

Fig. 8 Audio Visual and Information Source: Author

2) Samudraraksa Ship Museum inaugurated on August 31, 2005. In this area, visitors will found Samudraraksa ship that once sailed the ocean from Indonesia to Ghana, Africa. This ship has 18.2 meters long, 4.5 meters weight, and 2.25 meters in height. It also has 2 sails and 2 wheels. The museum has two rooms: the history room and the ship room. There is a digital interactive cinema inside the ship room, but the visitors have to pay Rp 25.000,00 to go inside it.

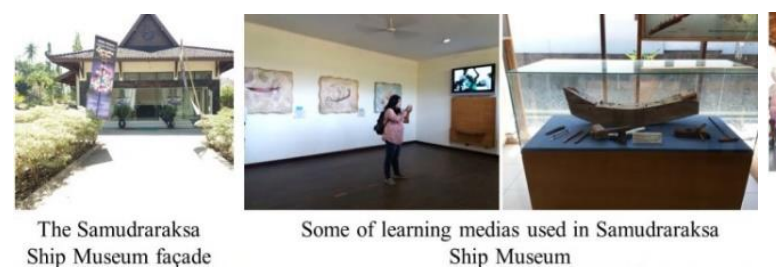

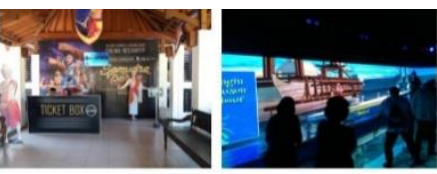

Digital interactive cinema http://www.beritamagelang.id/wahana-menariksinema-interaktif-museum-samudraraksa-candiborobudur (accessed August 27, 2019)

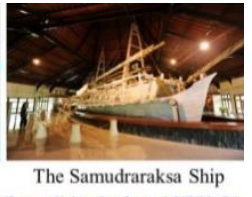

The Samudraraksa Ship
(https://situsbudaya id $/ 770-2 /$ (accessed August 27, 2019) (acces Aust 27,2019$)$

Fig. 9 Samudraksa Ship Museum Source: Author

3) Karmawibhangga Museum has some collections from Conservation Institute. It has two rooms. The first room is a restoration room. There are a lot of pictures about Temple restoration, and stone installation techniques, and some artifacts. The second room is the Karmawibhangga room. This room shows Karmawibhangga reliefs and occasionally also mixed with temporary exhibitions. The original Karmawibhangga reliefs are still embedded in the bottom of the Borobudur Temple for structural and ethical reasons. Only a few pictures of the Karmawibhangga reliefs are displayed in the Karmawibhangga Museum.

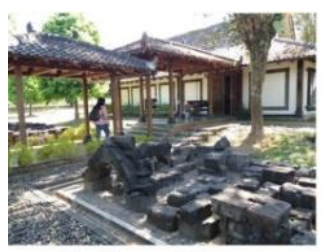

The Karmawibhangga Museum façade
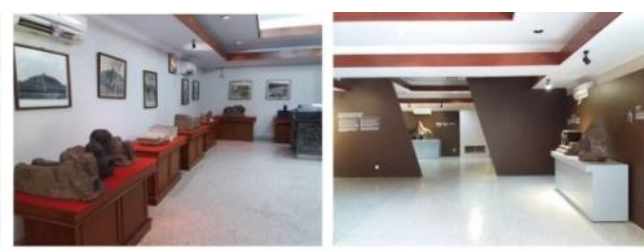

Some of learning medias used in Karmawibhangga Museum

Fig. 10 Karmawibhangga Museum

Source: Author 
b. Areas for non-educational purposes, include: elephants attraction, Dagi Hill, train stop, elephant house, Taman Wisata Restaurant, and Food and Crafts Center.

Table 2 Area for non-educational purposes

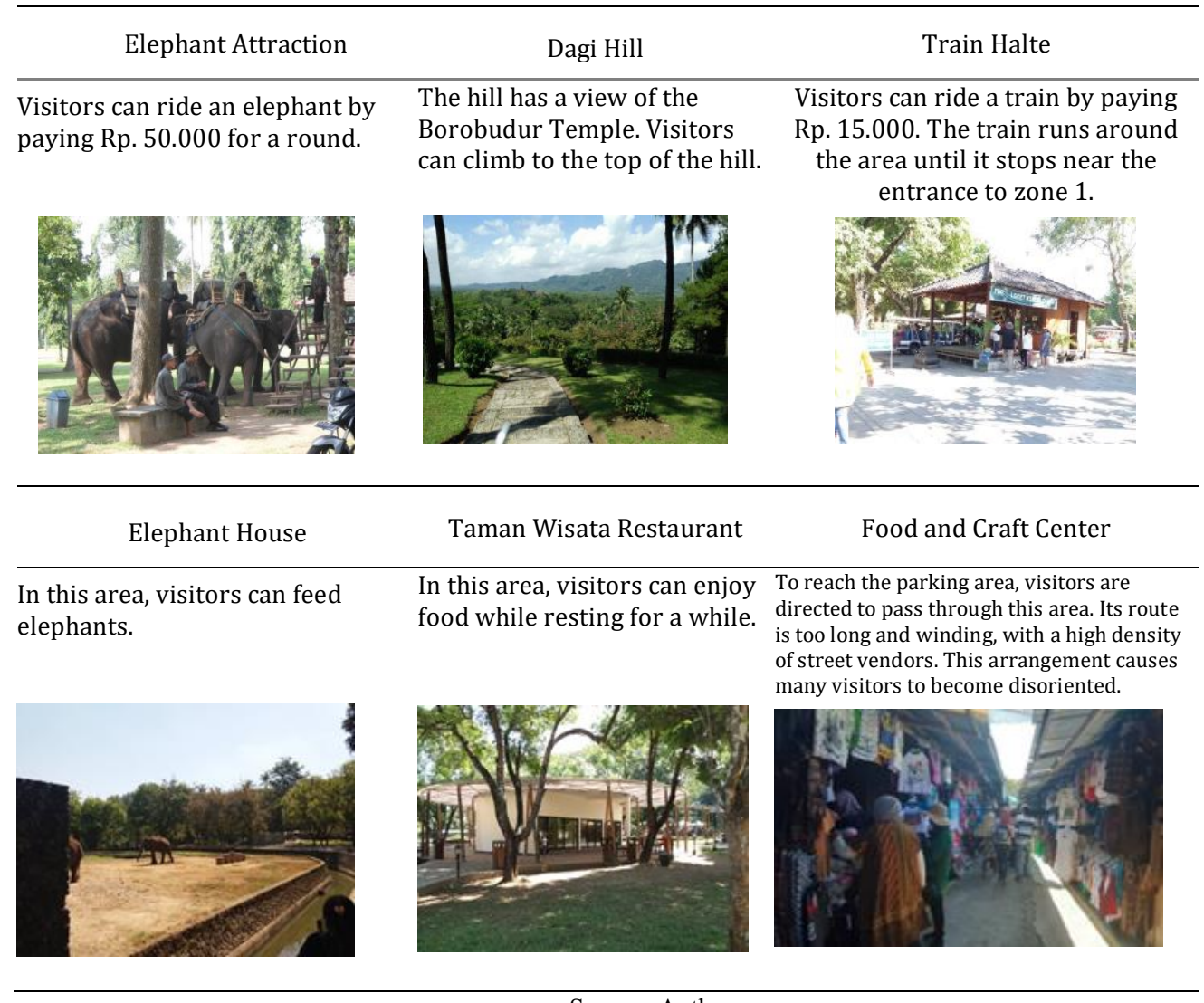

Source: Author

This research also recorded the visitors' movements, then patterned them as shown in Fig. 11. There were 5 types of visitors' movement pattern in TWCB, among others:
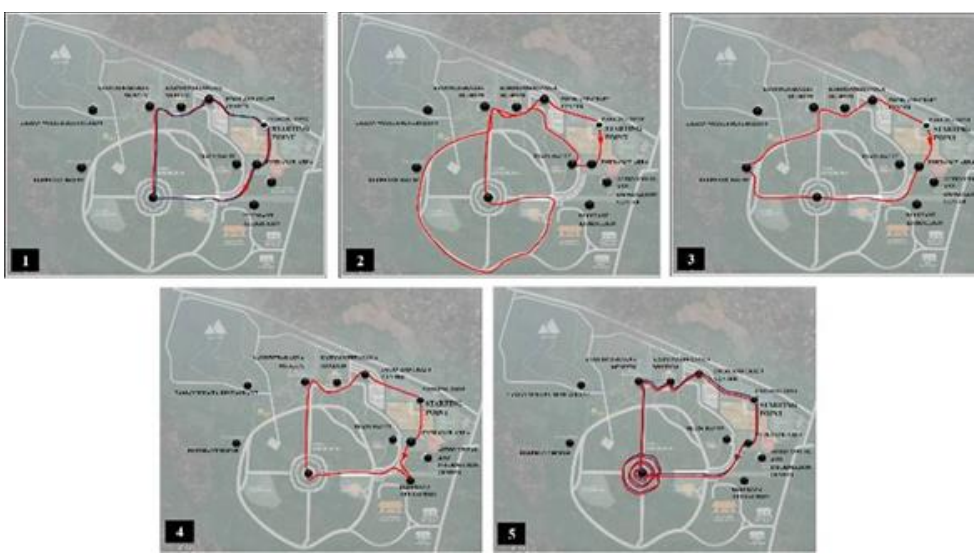

Fig. 11 Visitors' movement pattern

Source: Author

a. Type 1, chosen route: parking area - ticket booth - entrance area - Borobudur Temple - food and crafts center - parking area.

Visitors with this type of movement only visited Borobudur temple. Both domestic and international visitors walked in small groups (2-8 persons). They took selfies and strolled around the temple. They walked without a tour guide and did not visit educational purposed supporting attractions, such as the museums. From Borobudur courtyard, they climbed the temple from the eastern gate and exited 
from the northern part of the temple. Based on observation, type 1 is the shortest route. More than 50 persons in one group were found walking in this type because they have limited time.

b. Type 2, chosen route: parking area - ticket booth - entrance area - train ticketing - Borobudur Temple - food and crafts center - parking area.

Visitors with this type of movement walked from the parking area until the entrance area and continued the tour by taking a train. This train runs from the entrance area circling the TWCB area, to the main street in front of the temple entrance. From Borobudur courtyard, they climbed the temple from the eastern gate and exited from the northern part of the temple. This type of movement pattern was only found on domestic visitors. They usually visit in small or medium groups (8-20 persons). They walked without a tour guide. From the temple, visitors went to the parking area through the food and crafts center. They did not visit other supporting attractions. Based on observation, type 2 is the longest route.

c. Type 3, chosen route: parking area - ticket booth - entrance area - Borobudur Temple - elephants house - food and crafts center - parking area.

Visitors with this type of movement walked from the parking area until Borobudur Temple. From Borobudur courtyard, they climbed the temple from the eastern gate and exited from the western part of the temple to visit the elephant's house. This type was only found in domestic visitors in small family groups with kids.

d. Type 4, chosen route: parking area - ticket booth - entrance area - elephant's attraction Borobudur Temple - food and crafts center - parking area.

Visitors with this type of movement walked from the parking area until the entrance area, and then they visited the elephant's attraction. There were several attractions, such as feeding the deers, riding elephants, or renting a bicycle. From the elephant's attraction, they walked to Borobudur Temple. From Borobudur courtyard, they climbed the temple from the eastern gate, exited from the northern part of the temple, and went to the parking area through the food and crafts center. This type of movement pattern was only found in domestic visitors in small family groups with kids.

e. $\quad$ Type 5, chosen route: parking area - ticket booth - entrance area - Borobudur Temple - Samudraraksa Ship Museum - Karmawibhangga Museum - Food and crafts center - parking area Visitors with this type of movement walked from the parking area until Borobudur Temple. In Borobudur Temple, visitors walked in "pradaksina" style (Buddhist Tradition as an act of respecting the temple). Visitors entered the temple from the eastern gate and walked the level clockwise three times. From Borobudur courtyard, they exited from the northern part of the temple then visited Samudraraksa Ship and Karmawibhangga Museums. Visitors with this type of movement found in domestic and international with the tour guide. When domestic visitors visit the museums in big groups, some visitors usually withdraw from the group, wait outside, or walk directly to the parking area through the food and crafts center. It was also found that most international visitors did this type of movement with or without the tour guide.

Table 3 Summary visitors' movement patterns

\begin{tabular}{lll}
\hline \multicolumn{1}{c}{ Domestic Visitors } & \multicolumn{1}{c}{ International Visitors } \\
\hline - $\begin{array}{l}\text { Domestic visitors had many variations in } \\
\text { movement pattern } \\
\text { Domestic visitors preferred supporting } \\
\text { attractions for non-educational pur- } \\
\text { poses, such as riding and feeding ele- } \\
\text { phants, and riding a train } \\
\begin{array}{l}\text { Most domestic visitors went to support- } \\
\text { ing attractions with educational pur- } \\
\text { poses when they accompanied by the } \\
\text { tour guide }\end{array}\end{array}$ \\
$\begin{array}{l}\text { Most domestic visitors visited the } \\
\text { temple without "pradaksina" style }\end{array}$ & $\begin{array}{l}\text { International visitors didn't have many varia- } \\
\text { International visitors preferred supporting at- } \\
\text { tractions for educational purposes, such as mu- } \\
\text { seums } \\
\text { International visitors went to supporting attrac- } \\
\text { tions for educational purposes with or without } \\
\text { the tour guide } \\
\text { Most international visitors walked in "pra- } \\
\text { daksina" style while in Borobudur Temple, be- } \\
\text { cause of tour guide directions. }\end{array}$ \\
\hline
\end{tabular}

Source: Author 


\subsection{Discussion}

There were several differences between domestic and international visitors. International visitors had an educational purpose in visiting the heritage site. Most of them chose TWCB as the destination because they wanted to learn more about Borobudur History. They were more curious about the site, and they explored the area without feeling tired. The majority of international visitors used tour guides in each group. Most international visitors visited the Samudraraksa Ship and Karmawibhangga Museums. Hence, they gained more knowledge about the site. It means that visitors' interpretation goals which to educate visitors by providing an enjoyable, and even entertaining, experience for visitors is achieved.

Domestic visitors showed a different style of recreation. They preferred fun and relaxing activities without educational purposes, such as riding and feeding elephants, taking train ride taking pictures, or doing selfies. A number of domestic visitors did not visit Samudraraksa Ship and Karmawibhangga Museums because of several reasons. The first reason was they did not know the location of the museums. Some group of visitors that took the train might receive a few information from the driver. Moreover, there were no clear signages within TWCB. Therefore, visitors were unaware of the existence of museums. The other reason was domestic visitors were tired or bored after climbing up and down from Borobudur Temple. Other reasons that may impact the low visit rate of domestic visitors were the uninteresting façade and content of the museums. Tour guides also became one of the important actors that can direct domestic visitor's movement to visit museums. However, the majority of domestic visitors did not use a tour guide, so they ignored supporting attractions for educational purposes such as museums. It means that visitors' interpretation goals which to educate visitors by providing an enjoyable, and even entertaining, experience for visitors is not achieved. The importance of the existence of museums as supporting attractions for educational purposes should be able to attract more visitors and give them knowledge about Borobudur temple. However, as a matter of fact, information about Borobudur temple provided by the museums is considered lacking. It can be seen, among others, from the small percentage of the number of visitors to the museums.

Based on questionnaires, it is found that most respondents are under 29 years old. Responses on questionnaires showed that young people tend to not motivated to visit museums. This condition was seen more clearly in domestic visitors, where they deliberately came to TWCB for family recreation and looking for selfie photo spots. The lowest rank in domestic visitors' purpose in visiting TWCB was to learn the history of Borobudur Temple. Hence, one of the usefulness of the temple tourism park according to the Balai Konservasi Borobudur (Borobudur Conservation Center), namely to be able to instill a sense of love for the motherland for domestic tourists in general and adolescents in particular, has not been achieved.

One of Zone 2's functions is to break visitors' flow to various attractions in the park. Visitors inside the temple won't be crowded, because they split up to different attractions. Museums' existence should attract visitors to not visit the temple, therefore the temple will be sustained. Based on observation, it was found that visitors were directed by the circulation paths designed by TWCB management. It made visitors had to go to the temple first before they went to supported attractions. It made supported attractions in zone 2 could not serve its functions. This improper visitor management also affects how TWCB educates visitors before entering the temple area. Zona 2's function as a visitor flow breaker cannot be fully reached. Prohibition signs were often ignored by visitors. Due to improper circulation, knowledge about different perspectives of Borobudur Temple was also not well delivered.

In addition to the museums, audiovisual and information areas also provide visitors with some basic knowledge. However, during field observations, this area did not function as it should, hence no visitor came to this area. Whereas, if this area was functioning, visitors can be provided with some basic knowledge about Borobudur Temple as a World Cultural Heritage: what is allowed, and what is not allowed while on the temple, how to behave properly when in the temple, and so on. It is important considering the temple is a historic building that must be preserved. Price is also a factor that influences the visit rate in museums. However, this factor is not further discussed in this research, hence the opportunity to conduct other research is still wide open.

\section{Conclusions}

This research concludes that there were several differences between domestic and international visitors' behavior. The higher number of domestic visitors showed a lower visit rate in educational purpose attractions, such as Karmawibhangga Museum and Samudraraksa Ship Museum. They also did not use a 
tour guide. This condition was caused by three reasons, a) visitors were tired after climbing the Borobudur Temple, b) the location of the museums was not strategic, and c) the condition of the museums was less attractive. In this research, international visitors were well informed because of their high learning motivation. It was shown from the high visit rates in the museums and high visitors' willingness to go to supporting attractions for educational purposes as seen from visitors' movement patterns. The majority of international visitors were accompanied by tour guide, hence, they gained more knowledge about the site. Cultural differences between international visitors and TWCB stimulated different feeling of atmosphere. Therefore, they enjoyed every moment in Borobudur temple. They did not feel tired or bored because of the attractions in TWCB. They collected more knowledge from the area.

There are several recommendations for TWCB management. Circulation areas should direct visitors to go to the museums first before the temple. Therefore, it will more likely to increase visitors' visit rates in the museums. Uninteresting building and content packaging in museums could be one of the reasons why domestic visitors did not want to go to the museums. With more attractive packaging, visitors will spend more time in the museums before climb the Borobudur temple. Visitors will gain more knowledge with more enjoyable packaging. It might also discourage visitors from climbing the temple, furthermore, it will decrease the number of visitors in the temple. Hence, the Borobudur Temple carrying capacity is not exceeded.

\section{References}

Balai Konservasi Borobudur. (2014). 200 Tahun Penemuan Candi Borobudur [200 Years of Borobudur Temple Discovery]. Magelang: Balai Konservasi Borobudur.

Booth, S. (1993). Crisis management strategy, competition and changes in modern enterprises. London: Routledge.

Devi, M. C. (2017). Perilaku Adaptasi Pengunjung Domestik Terhadap Elemen Fisik Area Zona 2 Kawasan Wisata Candi Borobudur. Universitas Gadjah Mada, Yogyakarta.

Diarta, I. K. S. (2017). Between cultural preservation and tourism industry: dialectic relations in cultural her-itage tourism management in Tanah Lot and Borobudur Indonesia. E-Journal of Tourism (, 4, 100-109. Retrieved from https://ojs.unud.ac.id/index.php/eot/article/view/36403

Fyall, A., \& Garrod, B. (1998). Heritage tourism: at what price? Managing Leisure, 3(4), 213-228.

Hermawan, B., Salim, U., Rohman, F., \& Rahayu, M. (2016). Borobudur Temple as Buddhist Pilgrimage Destination in Indonesia: an Analysis of Factors that Affect Visit Intention. Journal of International $\begin{array}{lllll}\text { Buddhist } & \text { Studies, } & \text { 98-110. } & \text { Retrieved }\end{array}$ http://www.ojs.mcu.ac.th/index.php/JIBS/article/view/660/Budipdf

Horwarth, H. T. L. (2017). Borobudur-Yogyakarta-Prambanan baseline supply \& demand, market demand forecasts, and investment needs: market analysis and demand assessments to support the development of integrated tourism destinations across Indonesia. Retrieved from http://bpiw.pu.go.id/uploads/20170302_Borobudur_Market_and_Demand_Assessment.pdf

Presidential Decree. Presidential Decree No.1 Year 1992 concerning Management of Borobudur and Prambanan Temple Tourism Park and Their Environmental Controls. , 1 Keputusan Presiden Nomor 1 Tahun 1992 tentang pengelolaan Taman Wisata Candi Borobudur dan Taman Wisata Candi Prambanan serta pengendalian lingkungan kawasannya $§(1992)$.

Timothy, D. J., \& Boyd, S. W. (2003). Heritage tourism. Essex: Pearson Education Gate.

Wahyuningsih, I. (2016). Meninjau kembali tujuan pendirian dan fungsi museum-museum di kompleks Taman Wisata Candi Borobudur. Jurnal Konservasi Cagar Budaya, 10, 45-54. 